\title{
8
}

\section{Health implications of ionising radiation}

\author{
Tilman A. Ruff
}

\section{Abstract}

The biological effects of ionising radiation is one of the most disputed and politicised topics relevant to analysis of nuclear technologies, including nuclear power. The first part of this chapter addresses the nature and sources of ionising radiation and its effects on biology and human health, including important new evidence that points to these effects being greater than previously estimated. Because the field of radiation and health has such a politicised history and is beset with contestation and interference by vested interests, the second part draws a brief historical landscape of who's who in radiation and health, in the hope of assisting readers to navigate and consider some critical questions of history, motivation, and interests behind who is saying what and why. The third part considers potential sources of human origin of large-scale radiation exposures. 


\section{Nature, sources, and effects of ionising radiation}

\section{What is ionising radiation?}

Ionising radiation includes various kinds of transmitted energy. Some types, like $\mathrm{X}$ and gamma rays, are part of the electromagnetic spectrum that spans from long wavelength, low energy radio, micro- and infrared waves, through visible light and ultraviolet radiation, to short wavelength, high energy $\mathrm{X}$ and gamma rays. Other types of ionising radiation consist of subatomic particles and fragments of atoms. Both electromagnetic and particulate radiation of high energy are called 'ionising' because the various types (see Table 8.1) are of sufficient energy to eject one or more electrons from atoms (ionisation) and break chemical bonds. Whenever radiation is referred to in this chapter, unless otherwise specified, ionising radiation is meant.

Table 8.1 Common types of ionising radiation

\begin{tabular}{|l|l|l|l|}
\hline \multicolumn{2}{|l|}{ Ionising radiation type } & $\begin{array}{l}\text { Radiation weighting } \\
\text { factor (biological } \\
\text { effect, compared } \\
\text { with photons) }\end{array}$ & Stopped by \\
\hline $\begin{array}{l}\text { Electromagnetic } \\
\text { radiation } \\
\text { (photons) }\end{array}$ & $\begin{array}{l}\text { Gamma rays } \\
\text { (similar to X-rays) }\end{array}$ & 1 & $\begin{array}{l}\text { Penetrating (providing the } \\
\text { basis for the use of X-rays } \\
\text { for imaging), stopped by } \\
\text { dense materials (e.g. lead } \\
\text { or concrete), not by clothing }\end{array}$ \\
\hline $\begin{array}{l}\text { Subatomic } \\
\text { particles }\end{array}$ & $\begin{array}{l}\text { Alpha (helium } \\
\text { nucleus) and } \\
\text { other heavy } \\
\text { fission fragments } \\
\text { like atomic nuclei }\end{array}$ & 20 & $\begin{array}{l}\text { Outer layer of skin, a sheet } \\
\text { of paper (harm derives } \\
\text { from internal exposure, } \\
\text { e.g. when inhaled or } \\
\text { ingested) }\end{array}$ \\
\cline { 2 - 5 } & \begin{tabular}{l} 
Beta (electron) \\
\cline { 2 - 4 }
\end{tabular} & 1 & $\begin{array}{l}\text { A layer of clothing; some } \\
\text { can penetrate to basal layer } \\
\text { of human skin }\end{array}$ \\
\cline { 2 - 5 } & Neutron & $\begin{array}{l}5-20 \text { depending on } \\
\text { neutron energy }\end{array}$ & $\begin{array}{l}\text { Penetrating; concrete } \\
\text { or earth most effective } \\
\text { protection }\end{array}$ \\
\hline
\end{tabular}

${ }^{*}$ A weighting factor of 1 means that for this amount of radiation energy, the particular type of radiation causes the same amount of biological damage as $\mathrm{X}$ or gamma rays; a factor of 2 means that type of radiation is twice as biologically damaging as gamma rays of the same energy, and so on.

Source: Centers for Disease Control and Prevention (2015); European Nuclear Society (n.d.). 
Ionising radiation can be produced by the spontaneous decay of radioactive elements, which fragment into smaller atoms, often repeatedly, each step usually also releasing energy in the form of ionising radiation. These decay chains often have multiple intermediaries that are also radioactive, until they eventually end up as elements that are stable. The decay chain, the rate at which each step occurs, and the type of radiation emitted, are fixed physical properties of each radioactive element. The rate of radioactive decay is described by the half-life-the time it takes for half the amount of a radioactive element to disintegrate. Elements with long half-lives persist for long periods, but their radioactivity is less intense than for elements that decay rapidly. Many chemical elements exist in different atomic forms (known as isotopes, with the same number of protons but varying numbers of neutrons in their nucleus), some or all of which may be radioactive, in which case they are called radioisotopes.

Ionising radiation can also be produced, such as in an X-ray machine, when rapidly moving charged particles collide with a substance. Neutron radiation emitted by a nuclear explosion can induce radioactivity in materials that are not normally radioactive, such as by converting nitrogen in the air to carbon-14, which is radioactive with a half-life of 5,730 years.

Different types of radiation have widely differing capacities to penetrate tissues. Alpha particles are stopped by a thin layer of paper or clothing and do not penetrate through the dead upper layer of normal human skin. However, their high energy makes them highly damaging if taken internally, into the lungs or gut. Some beta particles (electrons) penetrate to the basal layer of skin where new cells are produced. Gamma and X-rays are highly penetrating, which is the basis for the value of X-rays in medical imaging. Thick concrete or lead are used to stop them.

\section{Radiation sources and exposure pathways}

People are exposed to radiation via different pathways-essentially internal or external. Penetrating radiation from cosmic sources travelling down through the atmosphere, from radioactive materials in or on the ground, in building materials, or in the air, irradiate people externally. Direct contact with a source of penetrating radiation causes greatest exposure to the part in closest proximity. Inhalation, ingestion (via food, water, or environmental sources like soil and dust, particularly in children), or contamination of wounds or other skin breaks can cause exposure to radioactivity from radioactive materials that get inside the 
body. In this case, even radiation that penetrates only very short distances can be harmful, especially if radioactive particles are retained in the body for long periods. Internal contamination, especially with substances that do not emit highly penetrating radiation (like plutonium, strontium, and tritium) are more difficult to measure and may be neglected in assessing radiation exposure.

Many biologically important radioisotopes behave chemically, and are therefore handled by our bodies, like other elements that we need (see Table 8.2). Some of these are concentrated in living things and also up the food chain, and may be recycled in the biosphere. For example, the concentration of cesium-137 in fish in freshwater lakes may be 10,000 times higher than the concentration in the water in which the fish live.

Table 8.2 Selected radioactive isotopes from nuclear power plants significant in human health impact

\begin{tabular}{|l|l|l|l|}
\hline Radioisotope & $\begin{array}{l}\text { Main type(s) } \\
\text { of radioactivity } \\
\text { emitted }\end{array}$ & Half-life & $\begin{array}{l}\text { Health significance and predominant } \\
\text { means of exposure }\end{array}$ \\
\hline lodine-131 & Beta, gamma & 8 days & $\begin{array}{l}\text { Ingestion, concentrated up food chain } \\
\text { (especially milk); concentrated in thyroid } \\
\text { gland; causes thyroid disease including } \\
\text { cancer -children most vulnerable }\end{array}$ \\
\hline Cesium-137 & Beta, gamma & 30 years & $\begin{array}{l}\text { External and ingestion, body handles like } \\
\text { potassium, the main positively charged } \\
\text { ion inside cells; bio-concentrated; } \\
\text { associated with many cancers; dominant } \\
\text { cause of radiation exposure to world's } \\
\text { people from atmospheric nuclear test } \\
\text { explosions to date, and nuclear power } \\
\text { plant accidents }\end{array}$ \\
\hline Strontium-90 & Beta & 28 years & $\begin{array}{l}\text { Ingestion, handled by the body like } \\
\text { calcium, concentrates in bones and } \\
\text { teeth; bioconcentrated; retained; } \\
\text { causes leukaemia, bone cancer }\end{array}$ \\
\hline Plutonium-239 & Alpha & $\begin{array}{l}24,400 \\
\text { years }\end{array}$ & $\begin{array}{l}\text { Inhalation, retained; internal hazard; } \\
\text { especially when inhaled, causes } \\
\text { lung cancer. Plutonium isotopes are } \\
\text { inevitably produced inside nuclear } \\
\text { reactors by the absorption of neutrons } \\
\text { by uranium atoms }\end{array}$ \\
\hline $\begin{array}{l}\text { Tritium } \\
\text { (hydrogen-3) }\end{array}$ & Beta & 12.3 years & $\begin{array}{l}\text { Ingestion, internal hazard; becomes } \\
\text { incorporated in water molecules, does } \\
\text { not bioaccumulate }\end{array}$ \\
\hline
\end{tabular}

Source: Based on UNSCEAR (1993: Annex B, 128-9). 
Radioactive materials may be solid, liquid, or gaseous. Materials, objects, and organisms that contain radioactive materials or become surface-contaminated by them emit radioactivity; whereas objects and organisms exposed to radiation but not containing radioactive materials are not a source of potential exposure or hazard to others. For example, people injected with a radioactive chemical for medical purposes become radioactive for a period; whereas someone undergoing diagnostic $\mathrm{X}$-rays or external radiotherapy for cancer treatment is not rendered radioactive.

The bulk of our natural background radiation exposure is derived from radon gas, the heaviest of the noble gases, a ubiquitous carcinogen produced by the decay of primordial uranium-235 and 238 and thorium-232 present in the Earth's crust. Radon decays via a number of intermediaries (polonium, bismuth, and tellurium), which are more reactive and attach to aerosols and dust in the atmosphere, which may lodge in the lungs when inhaled. These radon progeny deliver most of the radiation dose associated with radon. Radon is the second-most important cause of lung cancer worldwide, exceeded only by tobacco smoking.

In many parts of the world, medical radiation exposure has increased markedly in recent decades, and in some countries now accounts for similar (for example, Australia, the US) or greater (for example, Japan) levels of radiation exposure across the population than does naturally occurring radiation. This is particularly due to increasing use of CT scans (computed tomography, a sophisticated type of X-ray examination).

Most modern nuclear weapons contain both highly enriched uranium and plutonium. Uranium or plutonium can fission (split) in about 40 different ways, producing altogether some 300 different radioactive nuclides, with half-lives varying from a fraction of a second to many millions of years. Inside a nuclear reactor, uranium and plutonium are also fissioned, but the neutrons that propagate the controlled chain reaction in a reactor are slower than the 'fast' neutrons involved in a nuclear weapon exploding. In addition, because the initial fission fragments, which are mostly shortlived, are not dispersed in a reactor, their longer-lived decay products accumulate. Thus, a nuclear reactor accumulates proportionately more long-lived radioisotopes than are produced by a nuclear bomb. 
As well as creating hundreds of new radioactive elements that did not exist before (see Table 8.3), a nuclear explosion and the operation of a nuclear reactor both increase the total radioactivity from that of the starting material a million times or more.

Table 8.3 Common radioisotopes in routine releases from nuclear plants

\begin{tabular}{|l|l|}
\hline Airborne & Common isotopes released (atomic number) \\
\hline Type & Krypton (85, 85m, 87, 88) \\
Fenon $(131,131 \mathrm{~m}, 133,133 \mathrm{~m}, 135,135 \mathrm{~m}, 138)$ \\
Argon (41)
\end{tabular}

Source: Adapted from National Research Council (2012: 37-8).

\section{Why is ionising radiation of biological importance?}

Ionising radiation is intensely biologically injurious, not because it contains extraordinarily large amounts of energy, but because its energy is bundled and delivered to cells in large packets. The energy of a diagnostic X-ray, for example, is typically around 15,000 times as great as the energy of a chemical bond. A whole-body dose of ionising radiation of 4 gray (Gy) causes potentially lethal acute radiation sickness in humans. Yet the energy delivered to a $70 \mathrm{~kg}$ adult human body by 
that dose of radiation amounts to only 280 joules - the same amount of energy as the heat absorbed by drinking one $3 \mathrm{~mL}$ sip of hot (60 degrees Celsius) tea or coffee.

Large complex molecular chains, especially of DNA, define who we are, regulate many biological processes, and are both our most precious inheritance and the most vital legacy we pass on to our children. One of the strands of the double DNA helixes inside each of our cells is derived from our mother, the other from our father. These large molecules are particularly vulnerable to disruption by ionising radiation. Radiation may cause direct damage to DNA, or cause indirect damage through the production of highly reactive chemicals, like free radical ions, which then react with DNA. A variety of types of damage may result-single and double-strand DNA breaks, oxidative changes to the nucleotide bases that make up DNA, deletions of sections of DNA, and resulting gene and chromosomal damage. The frequency of chromosomal aberrations, particularly dicentric forms, in blood lymphocytes can be used within weeks of whole-body radiation to estimate the dose received. Stable and persistent chromosomal changes that do not kill affected cells, like translocations (rearrangements of segments of chromosomes), have been demonstrated at increased frequencies even more than 50 years after exposure in Japanese hibakusha (nuclear bombing survivors) and New Zealand nuclear test veterans (Wahab et al. 2008).

DNA damage from radiation can have various outcomes, including effective repair, cell death (especially at high doses), impaired function, induction of cancer, or result in DNA changes transmissable to subsequent generations. Cells have mechanisms to repair DNA damage, but these are not complete or error-free. DNA is most susceptible to radiation damage when cells are dividing, so rapidly dividing and growing tissues are most vulnerable, such as blood-forming cells in the bone marrow, germ cells in the ovary and testis, cells lining the gastro-intestinal tract, and hair follicles. Radiation exposure to a foetus in the womb can lead to foetal damage (such as mental retardation) and malformations. Young children and foetuses are especially sensitive to radiation effects, and a cancerprone mutation occurring early in prenatal life is likely to transmit to a larger number of daughter cells than a mutation occurring later, when a cell undergoing a mutation will produce fewer daughter cells.

The science of radiation and health is still evolving. It has often been considered that the same dose of radiation delivered quickly is one-anda-half to two times more injurious than the same total dose delivered 
over a longer time. However, as discussed later, recent evidence suggests that this is not the case. Bystander effects are a feature of many types of radiation, whereby radiation damage to one cell damages nearby cells, even without initial DNA damage occurring. Inflammatory responses are thought to be involved. Genomic instability describes radiation-related gene damage causing increased susceptibility to further damage, and can be transmitted from parent to daughter cells. Both bystander effects and genomic instability can be delayed.

\section{Radiation levels and effects}

Radiation is measured in different ways. The most basic unit of radioactivity measures the frequency of atomic disintegration-1 becquerel $(\mathrm{Bq})$ is 1 radioactive decay per second. The absorbed dose of radioactivity is measured by the gray-1 Gy is 1 joule of energy deposited per kilogram of mass (usually tissue).

The equivalent dose measures the biological effect of the energy absorbed for a particular organ or tissue-it is the absorbed dose multiplied by the relevant tissue weighting factor, which reflects how sensitive a tissue is to radiation effects. There are five groups of tissue weighting factors spanning a 40-fold difference in radiation sensitivity. Most sensitive are the gonads (ovary and testis); the next most sensitive group includes red bone marrow (where blood cells are made), stomach, colon, and lung. The effective dose is a summation of the equivalent doses to tissues and organs exposed, adjusting for the varying radiosensitivity of different tissues. It gives an indication of overall risk. Such summations are not an exact science, and are less meaningful where doses are divergent for different tissues. For example, a brain CT scan may involve a 40-50 milliGray ( $\mathrm{mGy}$ ) dose to the brain, which particularly increases the risk of brain cancer; however, this translates into an effective whole-body dose of around 4.5 milliSievert $(\mathrm{mSv})$ (Mathews et al. 2013). Both equivalent dose and effective dose are measured in sievert $(\mathrm{Sv})$. For penetrating radiation like $\mathrm{X}$ and gamma rays, the dose in Gy and $\mathrm{Sv}$ is the same.

The average global background level of radiation we are all exposed to from inhalation of radon gas produced by the decay of uranium in the Earth's crust, cosmic sources, soil and rocks, and ingestion of low levels of naturally occurring radioactive substances, is about $2.4 \mathrm{mSv}$ per year. A single back-to-front chest X-ray typically involves a dose of $0.01 \mathrm{mSv}$; 
a CT scan typically involves doses of 3-12 mSv or more. Acute exposures over $100 \mathrm{mSv}$ produce effects on chromosomes measurable by laboratory testing. Doses below $100 \mathrm{mSv}$ are generally categorised as 'low dose'.

Ionising radiation in doses over $100-250 \mathrm{mSv}$ causes acute effects detectable by commonly available blood tests, and symptoms of acute radiation sickness develop at higher doses. Doses over $100 \mathrm{mSv}$ cause both reversible and persistent effects to various organs. Acute symptoms are increasingly likely at acute doses above a few hundred $\mathrm{mSv}$; without intensive medical care, doses around $4 \mathrm{~Sv}(4,000 \mathrm{mSv})$ will be fatal for many of those exposed. Much higher doses targeted to particular body sites are used in treatment of various cancers (the cells of which usually divide faster than normal cells) when the purpose is to kill cancer cells. Some acute effects of radiation, such as skin burns, hair loss, sterility, and acute symptoms such as headache, nausea, and vomiting occur only above certain thresholds of radiation dose received. Recovery may occur from many of the effects of acute radiation sickness, especially with good medical care.

In contrast, any and all levels of ionising radiation exposure, including doses too low to cause any short-term effects or symptoms, are associated with increased risks of long-term genetic damage, chronic disease, and increases in almost all types of cancer, ${ }^{1}$ proportional to the dose. Radiation both increases the chance of developing cancer and brings its onset earlier. These excess risks persist for the lifetime of those exposed. It has been conclusively established that there is no dose of radiation below which there is no incremental health risk-all radiation exposure adds to long-term health risks. This applies also to natural background radiation. Higher background exposures in some geographic areas have been shown to be linked to adverse effects such as increased mutation rates, immunological changes, physical body changes, and increased cancer rates in many diverse plant and animal species, including humans (Møller and Mousseau 2013). Even before the availability of recent data on unexpectedly high and early cancer rates in children following CT scans, it was estimated that $2.5 \mathrm{mSv}$ of natural background radiation to the bone marrow each year would be the cause of up to 30 per cent of childhood leukaemia (Wakeford, Kendall, and Little 2009).

1 Cancers are often considered in two broad types - cancers of blood-forming organs (leukaemia), and cancers of solid organs. 
Arguably the most authoritative and rigorous periodic assessments of radiation health risks are the Biological Effects of Ionizing Radiation (BEIR) reports produced by the US National Academy of Sciences. However, the most recent report, BEIR VII (Committee to Assess Health Risks from Exposure to Low Levels of Ionizing Radiation 2006), was published in 2006, and substantial new evidence has accumulated since then. The BEIR VII report estimates that the overall increase in risk of solid cancer incidence (occurrence) across a population is about one in 10,000 for each $1 \mathrm{mSv}$ of additional radiation exposure. The increased risk for leukaemia is about 10 per cent of this. As about half of all cancers are fatal, the estimated increased risk of death from cancer is about half that-about 1 in 20,000 per $\mathrm{mSv}$.

The maximum permitted dose limit recommended by the International Commission on Radiological Protection (ICRP) and most national radiation protection agencies for any additional non-medical exposures for members of the public is $1 \mathrm{mSv}$ per year (corresponding to about 0.11 microSv per hour, a common unit of radiation exposure measurement) (ICRP 2009). Some authorities apply more protective criteria, for example, the US Environmental Protection Agency specified level for clean-up of radioactively contaminated sites is $0.12 \mathrm{mSv}$ per year (US EPA 2014).

There has been a consistent trend over time that the more we know about radiation effects, the greater the evidence indicates those effects to be. Maximum permitted radiation dose limits have never been raised over time; they have always been lowered. For example, from 1950 to 1991, the maximum recommended whole-body radiation annual dose limits for radiation industry workers declined from approximately 250 to $20 \mathrm{mSv}$. These recommended dose limits are not doses below which there is no health risk. Rather, they represent the most recent compromise between safety and optimally protecting people on the one hand, and commercial and other vested interests and cost considerations on the other.

Ionising radiation also increases the risk of occurrence and death from some non-cancer diseases, including cardiovascular and respiratory disease. This has been clearly demonstrated at moderate and high doses, and recent evidence indicates that circulatory disease mortality also increases at low total doses and dose rates, such as occur in many nuclear industry workers. The increased risk of death from heart and other circulatory diseases is estimated to be comparable in magnitude to the radiation- 
related cancer risk, meaning that the total extra risk of dying because of exposure to radiation is likely to be around double the increased risk of death from cancer alone (Little et al. 2012).

One important factor in understanding radiation health effects is that small doses received by a large number of people may cause significant consequences. For example, a UK study showed that the great majority (over 85 per cent) of radon-related lung cancer deaths in the UK occurred among people living in homes where the level of radon was less than 100 becquerel per cubic metre $\left(\mathrm{Bq} / \mathrm{m}^{3}\right)$ of air, well below the level recommended as warranting remedial action of $200 \mathrm{~Bq} / \mathrm{m}^{3}$ (Gray et al. 2009). An additional average radiation dose across a population of 100 million people of only $1 \mathrm{mSv}$, using the traditional risk estimates above, can be expected to result in an additional 10,000 cancer cases.

\section{Populations with increased vulnerability to radiation health harm}

Radiation risk is not uniform across a population. It is highest in very young children and declines gradually with age. Infants are overall about four times as sensitive to radiation's cancer-inducing effects as middleaged adults (Committee to Assess Health Risks from Exposure to Low Levels of Ionizing Radiation 2006). A single X-ray to the abdomen of a pregnant woman, involving a radiation dose to the foetus of about $10 \mathrm{mSv}$, was shown in pioneering studies by Alice Stewart in the UK in the 1950s to increase the risk of cancer during childhood in her offspring by 40 per cent (Doll and Wakeford 1997).

In the BEIR VII assessment, following uniform whole-body exposure to the same level of radiation, women and girls are 52 per cent more likely to develop cancer than men and boys, and 38 per cent more likely to die of cancer than males. The difference is greatest at younger ages of exposure-for the same exposures occurring between zero and five years of age, girls are 86 per cent more likely to develop cancer than boys (Makhijani, Smith, and Thorne 2006: 35-40).

The greater vulnerability of children than adults to radiation damage is substantial-exposures in infancy (below one year of age) for boys are 3.7 times more likely to lead to cancer than the same exposure for a 30-year-old man; for infant girls compared with 30-year-old women, that risk is 4.5 times greater (Committee to Assess Health Risks from 
Exposure to Low Levels of Ionizing Radiation 2006: 470-99). These differences relate to both increased sensitivity of the young and the usually longer remaining years of life for effects to become manifest. The relationship between overall cancer risk and age is depicted in Figure 8.1.

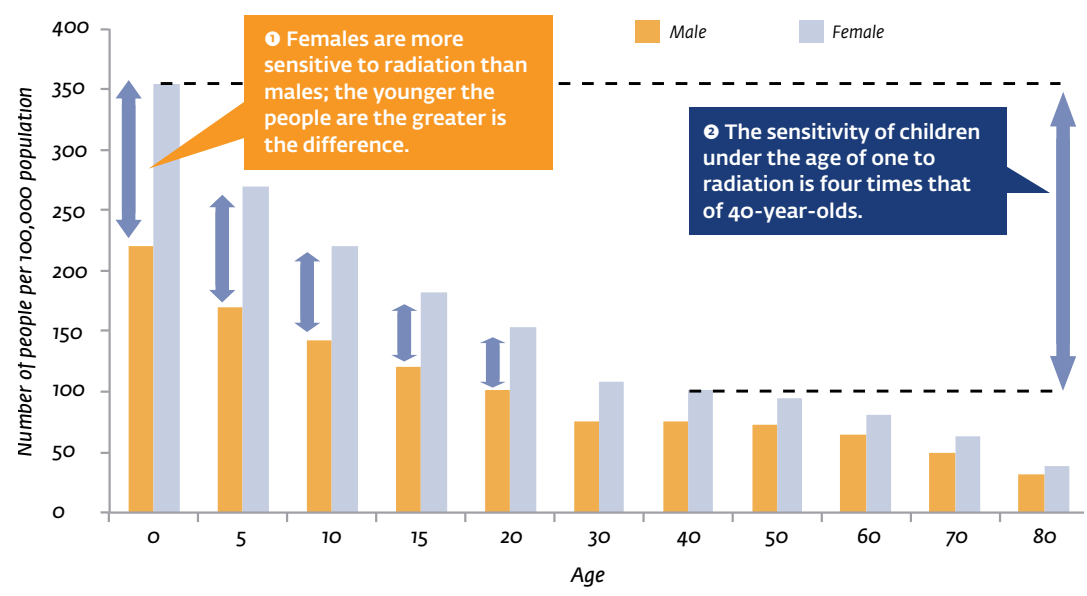

Figure 8.1 Increased lifetime cancer risk by age and gender associated with an extra radiation dose of $10 \mathrm{mSv}$

Source: NAllC (2012), based on data from Committee to Assess Health Risks from Exposure to Low Levels of lonizing Radiation (2006).

Increased vulnerability of young people also applies to the non-cancer health risks of radiation exposure. In recent research for the British population, by way of example, a similar increase in risk occurs associated with younger age of exposure for cardiovascular disease. It was estimated that the increased lifetime risk of death from circulatory disease is about 10 times higher for a child exposed to radiation before 10 years of age compared with exposure after age 70 . Similarly, an exposed child's risk of death from solid cancer was estimated to be more than 20 times higher than for exposure occurring over the age of 70 , and about double that associated with the same exposure at age 30-39 years (Little et al. 2012).

The combined effects of exposure during early childhood and greater female susceptibility can be dramatic. For example, for intake of fluid containing the radioactive isotope strontium-90, infant girls exposed to the same level of contamination are assessed to have a 20.6-fold higher risk of breast cancer than women aged 30 years. For the same level of contamination of ingested iodine-131, the risk for infant girls compared 
with 30-year-old women is 32.8 times higher. This means that for the same level of radioactive contamination, the cumulative breast or thyroid cancer risk by ingestion over the first five years of life for girls is greater than that accumulated by women over their entire adult lives (Makhijani, Smith, and Thorne 2006: 40).

These differential vulnerabilities are obscured by averaging risks across populations.

\section{The evolving evidence of radiation-related health harm}

The long-term follow-up studies of Hiroshima and Nagasaki hibakusha have provided the bulk of historic data on which radiation health risks have been estimated - and based on which the recommended dose limits for nuclear industry and other radiation-exposed workers and the public have been set. The most recent published data from ongoing studies of the Hiroshima and Nagasaki survivors confirm a linear dose-response relationship between radiation dose and overall cancer risk, with no threshold (Ozasa et al. 2012). They also suggest that the risk per unit dose is greater at lower radiation doses. They do not show a reduction in cancer risk for the same total exposure when radiation is delivered over a longer time, as some bodies such as the ICRP still assume. They certainly do not show an absence of evidence of increased cancer risk at doses less than $100 \mathrm{mSv}$, as Japanese official bodies and educational materials for students and teachers still claim (Cabinet Office et al. 2016). Even within the context of Japan, the extreme and unfounded nature of this official mantra is contradicted by the Japanese government recently awarding workers' compensation to a man who developed leukaemia after working for 14 months as a clean-up worker at the damaged Fukushima Daiichi nuclear plant (Soble 2015). The level of radiation exposure required to claim workers' compensation in Japan is $5 \mathrm{mSv}$ per year.

The Japanese survivor studies, however, have a range of methodological flaws that lean towards underestimation of radiation risk (see Table 8.4) (Richardson, Wing, and Cole 2013; Mathews et al. 2013). The most significant gaps are that the hibakusha studies reflect a hardy survivor population, misclassify some exposures, include relatively few people who received low radiation doses, and miss cancer deaths occurring in the first five years and cancer cases over the first 13 years. 


\section{Table 8.4 Features of the Japanese hibakusha Life Span Study that tend to underestimate radiation health risks}

\begin{tabular}{|c|c|}
\hline $\begin{array}{l}\text { Selected hardy } \\
\text { population }\end{array}$ & $\begin{array}{l}\text { Those who survived the atomic bombings were a selected } \\
\text { population who had already survived the hardship, poor nutrition, } \\
\text { and deprivation of war. The added stresses of the atomic } \\
\text { bombings would favour the survival of those who were hardier, } \\
\text { better nourished, less likely to be injured or suffering pre-existing } \\
\text { health problems, and thus less vulnerable to the adverse health } \\
\text { effects of the bomb. }\end{array}$ \\
\hline $\begin{array}{l}\text { Early cancer deaths } \\
\text { missed }\end{array}$ & $\begin{array}{l}\text { Cancer deaths were not recorded until 1950-cancer deaths } \\
\text { between } 1945 \text { and } 1950 \text { were not counted. }\end{array}$ \\
\hline $\begin{array}{l}\text { Early leukaemia } \\
\text { and cancer cases } \\
\text { missed }\end{array}$ & $\begin{array}{l}\text { Leukaemia cases were only counted from } 1950 \text {, and other } \\
\text { cancer cases only from } 1958,13 \text { years after the atomic } \\
\text { bombings; whereas increases can be expected to have begun } \\
\text { by } 1947-48 \text {. }\end{array}$ \\
\hline $\begin{array}{l}\text { Some counted } \\
\text { as unexposed to } \\
\text { radiation were in fact } \\
\text { exposed }\end{array}$ & $\begin{array}{l}\text { Those who were between } 2.5 \mathrm{~km} \text { and } 10 \mathrm{~km} \text { from the epicentre } \\
\text { were considered 'unexposed'; many of these will have had some } \\
\text { exposure. Those who entered the bombed cities in the week after } \\
\text { the bombings were exposed to neutron-induced radioactivity } \\
\text { (estimated at } 82 \mathrm{mSv} \text { colon (average internal organ) dose in } \\
\text { Hiroshima on day two). People in the vicinity of Hiroshima who } \\
\text { were exposed to radioactive fallout as black rain had high mortality } \\
\text { in } 1950-62 \text {, yet were counted in the control group. All these } \\
\text { types of exposures were ignored, which would tend to reduce the } \\
\text { observed effects of radiation exposure on survivors. Further, in } \\
\text { various analyses, doses of }<10 \text { mGy were counted as unexposed. }\end{array}$ \\
\hline $\begin{array}{l}\text { Dose estimates are } \\
\text { uncertain }\end{array}$ & $\begin{array}{l}\text { While repeated careful dose estimates for hibakusha have been } \\
\text { made, considerable uncertainty about individual doses remains. }\end{array}$ \\
\hline $\begin{array}{l}\text { Relatively few } \\
\text { hibakusha received } \\
\text { low radiation doses }\end{array}$ & $\begin{array}{l}\text { There were about } 70,000 \text { survivors estimated to have received } \\
\text { low doses (<100 mSv). This is considerably fewer than in recent } \\
\text { worker and CT scan studies, which have greater statistical power } \\
\text { to detect an effect, and with greater precision. }\end{array}$ \\
\hline $\begin{array}{l}\text { Missing radiation } \\
\text { doses were } \\
\text { disproportionately } \\
\text { among the more } \\
\text { highly exposed }\end{array}$ & $\begin{array}{l}\text { In both Hiroshima and Nagasaki, about 3,500 survivors with } \\
\text { 'missing doses', who were close to the bombs and therefore } \\
\text { highly exposed, generally young and commonly migrated out } \\
\text { of the bombed cities, were disproportionately excluded from } \\
\text { analyses. }\end{array}$ \\
\hline $\begin{array}{l}\text { Immortal person } \\
\text { time }\end{array}$ & $\begin{array}{l}\text { Survivors were enrolled into the Life Span Study in 1950, but } \\
\text { estimation of radiation doses and counting of cancer cases } \\
\text { among those enrolled were not complete until } 1965 \text {. Thus some } \\
\text { people were included in the study for up to } 15 \text { years during } \\
\text { which time any cancers they developed were not included. }\end{array}$ \\
\hline $\begin{array}{l}\text { Radiation-related } \\
\text { cancers are still } \\
\text { occurring }\end{array}$ & $\begin{array}{l}\text { Particularly for those exposed at a young age for whom the risks } \\
\text { are highest, excess cancer cases will continue to occur as long } \\
\text { as they live. }\end{array}$ \\
\hline $\begin{array}{l}\text { Stigma and } \\
\text { discrimination }\end{array}$ & $\begin{array}{l}\text { Many hibakusha suffered ostracism, discrimination, and social } \\
\text { isolation with reduced opportunities for marriage, providing } \\
\text { motivation for concealment of their status as hibakusha. }\end{array}$ \\
\hline
\end{tabular}

Sources: Author's original work; Richardson, Wing and Cole (2013); Mathews et al. (2013). 
Powerful new epidemiological studies over the past decade have provided estimates both more accurate and demonstrating greater radiation-related health risks than previously estimated (Kitahara et al. 2015). These studies are made possible by electronically linking data on radiation exposure, especially at low doses, and health outcomes for large numbers of people, such as for children who underwent a CT scan funded by national health insurance, who subsequently developed a cancer reported to their local cancer registry. The most important of these new studies are outlined below.

\section{Childhood leukaemia near nuclear power plants}

Apparent excesses of leukaemia occurring in children living near nuclear power plants have caused concern and controversy over decades. Perhaps the most prominent was an excess of leukaemia and lymphoma cases around the Sellafield nuclear plant in England in the 1980s, which was the location of the Windscale accident and fire in 1957, and, before the 1986 Chernobyl disaster, the most radioactively polluting nuclear facility in Europe. An investigation recommended by a governmentcommissioned committee unexpectedly found that the risks for leukaemia and lymphoma were higher in children born within $5 \mathrm{~km}$ of Sellafield, and in children with fathers employed at the plant, particularly those recording high radiation doses before their child's conception (Gardner et al. 1990). A 2007 meta-analysis supported by the US Department of Energy examined all of the reliable data available worldwide, confirming a statistically significant increase in leukaemia for children living near nuclear power plants (Baker and Hoel 2007).

The most definitive findings come from a large national German study, which examined leukaemia among children living near any of Germany's 16 operating nuclear plants over a 25 -year period. It showed that the risk of leukaemia more than doubled for children living within $5 \mathrm{~km}$ of a nuclear plant, with elevated risk extending beyond $50 \mathrm{~km}$ from a plant (Kaatsch et al. 2008). This finding was highly statistically significant. A subsequent but less powerful study in France found a similar increase. While these findings have been challenged on grounds that they are not explicable on the basis of prevailing estimates of the radiation exposures involved and their predicted effects, this in no way changes the strength of the association, whatever its cause, and no possible cause other than radiation has been identified. Actual data on real-world outcomes always trumps any theoretical model. 


\section{Childhood cancer following CT scans}

A major part of growing medical radiation exposure worldwide is due to CT scans. These use X-rays to take spiralled images to show closely spaced cross-sections of the body, and involve effective whole-body exposures of 1 to 10 or more (up to $20+$ ) mSv. A number of studies have now documented cancer risks following CT scans in children that are much greater than previously estimated. The largest to date is an Australian study of cancer risk after CT scans in 680,000 young people (aged less than 20 years), compared with the 10.3 million young Australians who did not have CT scans, over the same 20-year period (Mathews et al. 2013). The study involved 10 times as many people exposed and four times the total radiation dose as the Japanese survivor data for low doses of radiation (approximately 70,000 people who received less than $100 \mathrm{mSv}$ ).

The CT study demonstrated a 24 per cent increase in cancer in the decade following one CT scan delivering an average effective dose of only $4.5 \mathrm{mSv}$, and 16 per cent greater cancer risk for each additional scan (Mathews et al. 2013). Cancers occurred as early as two years after exposure. The average length of follow-up after the first CT scan was close to a decade, so new cancers will continue to occur through the life of exposed individuals. For similar ages of exposure and lengths of followup, the risk for leukaemia related to CT radiation was similar to that among hibakusha; however, the risk of solid cancer in the more powerful CT study was 12.5 times higher for brain cancer (Smoll et al. 2016) and nine times higher for solid cancers overall (Mathews et al. 2013) than in the hibakusha studies. The findings for leukaemia and brain cancer are quite similar in the Australian study and a smaller British study (which did not include other solid cancers) (Pearce et al. 2012).

The Australian study is now the largest population-based study of lowdose radiation ever conducted, in children who are the group most susceptible to radiation, giving its results great importance. These studies fill important gaps in the hibakusha studies regarding low doses, early onset cancers, and children. Longer term follow-up of these children and examining the risks associated with nuclear medicine procedures are underway and can be expected to yield important new findings in coming years. Already the results of these studies warrant upward revision of radiation risk estimates and reduction of recommended radiation dose limits in order to effectively protect the most vulnerable. One strong likelihood is that the dose-response curve for radiation-related cancer risk 
is not linear as generally assumed, but steeper at low doses, with a greater effect per $\mathrm{mSv}$ at low doses than at higher doses, particularly for children (Smoll et al. 2016). It is also likely that the greatest increase in cancers related to radiation is in those occurring early after exposure, among people most susceptible.

\section{Cancer risks for nuclear industry workers}

Updated results of large long-term studies of hundreds of thousands of nuclear industry workers coordinated by the International Agency for Research on Cancer on risks for leukaemia (Leuraud et al. 2015) and cancer (Richardson et al. 2015) were reported in 2015. The studies included 308,000 workers from France, the UK, and the US, some of them followed up since 1944, with a mean follow-up period of 26 years, to an average age of 58 years, and involving total measured colon radiation dose (a common measure of internal organ exposure) more than five times the collective dose received by hibakusha who received low doses. The mean dose rate for the workers involved was only $1.1 \mathrm{mGy}$ per year, less than background radiation in most places, with cumulative doses well within the current most widely recommended dose limit for nuclear industry workers of an average of no more than $20 \mathrm{mSv}$ per year (the average total dose received by each worker in the study during their average 12-year employment in the industry was close to $20 \mathrm{mSv}$ ).

The solid cancer risk was statistically compatible with, but 50 per cent higher than, that in 20-60-year-old male bibakusha, and will continue to rise as the subjects age. The leukaemia risk identified was similar to that in 20-60-year-old male hibukusha. It is important to note that at the average age of workers in the study of 58 years, the incidence of cancer and chronic diseases is beginning to accelerate.

These large and powerful studies show risks even at very low-dose rates and doses well within recommended occupational limits. They do not support a reduction of risk for the same total dose if the dose is delivered over a longer time (low-dose rates compared with high-dose rates). BEIR VII assumes a dose rate reduction factor for low-dose rates of 1.5 and a number of radiation protection bodies such as the ICRP use a factor of 2, whereas such reduction factors were abandoned by the World Health Organization (WHO) in its 2013 report on health consequences of the Fukushima nuclear disaster (WHO 2013), and by the United Nations Scientific Committee on the Effects of Atomic Radiation (UNSCEAR) 
in 2013 (UNSCEAR 2014). Together, the CT scan and worker studies conclusively demonstrate the absence of a threshold for ionising radiationrelated cancer risk.

\section{Cancer and other health effects in people exposed to the Chernobyl and Fukushima Daiichi nuclear disasters}

The effects of the 1986 Chernobyl nuclear disaster have recently been independently reviewed (Fairlie 2016). Major findings include:

- an estimated 40,000 excess fatal cancers in Europe by 2065;

- 6,000 additional cases of thyroid cancer have already occurred. An additional 10,000 are expected by 2065. Initially these were almost exclusively in children; more recently, cases are also occurring at older ages. Increases in thyroid cancer have also been found in a number of other countries, such as Austria, Slovakia, the Czech Republic, and Poland. It is likely that at least some of this increase is due to Chernobyl;

- increasing rates of leukaemia and thyroid cancer among the estimated total 600,000-800,000 clean-up workers, as well as increased risk of cataracts at a lower threshold dose than previously thought (100-250 mGy);

- despite international agencies assuming that no increases in congenital malformations will be detectable in Chernobyl-contaminated areas, increases in nervous system birth defects have been found in the highly contaminated Rivne-Polissia region of Ukraine. These include neural tube defects like spina bifida, anencephaly, microcephaly, and small or missing eyes (Dancause et al. 2010);

- increasing rates of breast cancer in the most contaminated regions of Belarus and Ukraine; and

- dislocation of lives due to radioactive contamination and long-term worry about radiation risks can also have adverse heal th consequencesamong clean-up workers, depression and post-traumatic stress disorder rates are elevated even decades later, and mothers of exposed young children are at high risk of depression, anxiety, and other mental disorders.

While various Japanese and international agencies stated that no radiationrelated adverse health consequences were likely to be detected as a result of the Fukushima nuclear disaster, this implausible assessment has already been shown to be in error. The Japanese government's Reconstruction 
Agency estimated 3,407 nuclear-disaster related deaths to early 2016 in Fukushima prefecture (including due to inadequate evacuations and continuing care of chronically ill patients in contaminated regions, and suicides). A lack of comprehensive health screening and follow-up for the exposed population and inadequate cancer registries in many of the relevant areas of Japan mean that the capacity to detect and respond to health problems is constrained.

The one area where more effective screening is taking place in Fukushima prefecture (but not in other fallout-affected areas) is in periodic ultrasound examinations of the thyroid glands of children aged less than 18 years at the time of the disaster. Even though 24-29 per cent of the eligible population have not participated (to September 2016), such an active search for thyroid abnormalities can be expected to find more cysts and nodules than would come to medical attention in the absence of an active screening program, the findings to date suggest that despite thyroid radiation doses being estimated to be much lower in Fukushima than following the Chernobyl disaster, early evidence of an epidemic of thyroid cancer appears to be emerging. This evidence is summarised on the basis of 113 thyroid cancers in children in Fukushima diagnosed to the end of 2015, including 51 diagnosed in the second round of ultrasound screening (Tsuda et al. 2016a, 2016b):

- the rates of thyroid cancer detected initially in Fukushima were between 20 and 50 times higher than the Japanese national average;

- among the cancers diagnosed on the second ultrasound screening, two years after the first, the rate is still 20 to 38 times the national average, likely too great a difference to be explained by active screening alone;

- within Fukushima prefecture, the rate in the most contaminated district was 2.6 times higher than in the least contaminated areas; and

- the cancers diagnosed were not disproportionately benign-92 per cent of the operated cases had spread outside the thyroid gland, to lymph nodes, or to distant organs.

To September 2016, the number of reported thyroid cancer cases among children screened in Fukushima had increased to 145. 


\section{Radiation effects for non-human species living in contaminated areas}

Timothy Mousseau and Anders Møller's chapter in this volume outlines the extraordinary body of evidence-much of it gathered by them-on the effects of radiation on non-human biota living in contaminated areas of Chernobyl and Fukushima. In virtually every species and ecological community studied-from soil bacteria and fungi through trees, to various insects, spiders, diverse birds, and large and small mammalsadverse biological effects have been found, in direct proportion to the degree of radioactive contamination, without any apparent threshold, and with most effects apparent across the range of 1-10 mGy per year.

It is biologically implausible that humans will be immune from similar effects. As for recent human data, there is a similar trend for non-human species of larger biological impacts of radiation to be identified than previously recognised. The work of Mousseau and Møller demonstrates the importance of assessing effects on organisms in the real ecological context and conditions under which they live, and of including the most vulnerable developmental stages, tissues and organs, including gametes and embryos.

\section{A brief history of radiation and health}

\section{Delays in translating evidence into policy and practice, undue influence of vested interests, and corruption of science and medicine}

Historically, it has often taken decades, in some cases many decades, for evidence about public health risks to be translated into policy and action, particularly when the risks are associated with long lag periods between exposures and consequences, and when there are powerful vested interests at stake. Examples include smoking, asbestos, alcohol, unhealthy 'junk' food, fossil fuels, and low-dose radiation. For radiation and fossil fuels especially, an additional insidious factor fuelling denial, inattention, and inertia is that most victims are not able to be identified with a face and a name. There is generally no way to distinguish a cancer (or a heart attack) caused by radiation from one caused by smoking or chemical exposures or other factors, and most cancers have a number of interacting causes. 
So many radiation victims cannot be personally identified. They melt into the crowd. Radiation cannot be seen or felt or smelt or tasted. Except for acute radiation sickness occurring following high doses, you cannot feel it doing you harm. Long-term genetic damage and cancer typically manifest years, often decades, later. These factors mean that effects of radiation are often inadequately recognised or downplayed. However, this does not make the people and families affected any less real, or less deserving of efforts to prevent suffering and premature death. An example is the global fallout from atmospheric nuclear weapons test explosions, which every human being carries in their body, and over time will cause over 2 million cancer deaths and as many non-fatal cancers (Ruff 2015). Yet apart from some test veterans and some members of downwind communities, most of the individuals suffering and dying from these excess cancers will not be personally identifiable.

A wider and historical context is crucial to understanding the dynamics, institutions, and conflict that enmeshes the field and evidence of radiation health effects. Nuclear weapons are by far the most destructive of all weapons, constituting the paramount existential threat to life on Earth. Yet they are central to the politics and practices of some states, including the largest. Almost half a century after nuclear-armed states made legally binding commitments in the Nuclear Non-Proliferation Treaty to abolish their nuclear weapons, there are still 14,930 nuclear weapons (Kristensen and Norris 2017), no disarmament negotiations underway, and all nine nuclear-armed states are investing massively (a projected US\$1 trillion investment over the next 30 years in the US alone) in the modernisation and deployment of their nuclear weapons for the indefinite future (Kristensen and McKinzie 2015). Treaties to prohibit and eliminate chemical and biological weapons, landmines, and cluster munitions are largely being implemented. A historic treaty that for the first time comprehensively prohibits nuclear weapons was finally adopted at the United Nations (UN) on 7 July 2017 by 122 nations. The treaty is based on the clear evidence that the most indiscriminate and inhumane weapons of all cannot be used for any legitimate purpose and effectively constitute global suicide bombs. However, the treaty has been opposed by all nuclear-dependent and nuclear-armed states, which continue to refuse to eliminate their nuclear arsenals.

Over the past 70 years, the perceived potency of nuclear weapons as instruments of state power has been a driver not only for their proliferation, but for the uranium enrichment plants, nuclear reactors, and spent fuel 
reprocessing plants that provide the capacity and materials to build them. Following US President Dwight Eisenhower's 'Atoms for Peace' speech at the UN in 1953, nuclear research and isotope production reactors and nuclear power plants were actively promoted globally. US Department of Defense consultant Stefan Possony advocated to the Psychology Strategy Board in 1953: '[T] he atomic bomb will be accepted far more readily if at the same time atomic energy is being used for constructive ends' (quoted in Kuznick 2011). US Atomic Energy Commissioner Thomas Murray promoted nuclear power specifically in Japan:

Now, while the memory of Hiroshima and Nagasaki remain so vivid, construction of such a power plant in a country like Japan would be a dramatic and Christian gesture which could lift all of us far above recollection of the carnage of those cities (quoted in Kuznick 2011).

Beginning with the Manhattan Project, accompanying the massive investment in burgeoning Cold War nuclear arsenals, donation of research reactors by both the US and the USSR to over 100 countries, and promotion and subsidisation of nuclear power, there has been a concerted and ongoing effort to manipulate, distort, downplay, and sideline evidence of the extent of radiation-related health risks. This has involved the large institutions, both government and private, with strong funding, career, institutional, political, and commercial vested interests in either or both nuclear weapons and reactors. Unwelcome research has frequently been suppressed and shut down; independent researchers collecting and gathering unwelcome evidence have been undermined, de-funded, dismissed, and discredited. While a detailed history of radiation health is not feasible here, it is important to recognise the courage and salute the scientific contributions of independent scientists and physicians like Alice Stewart, George Kneale, Thomas Mancuso, Edward Martell, and Carl Johnson, to name but a few who have suffered because their seminal scientific work on the extent of radiation health risks was unwelcome for powerful vested nuclear interests (Quigley, Lowman, and Wing 2012).

A tobacco industry executive in 1969 explained: 'Doubt is our product since it is the best means of competing with the "body of fact" that exists in the mind of the general public. It is also the means of establishing a controversy' (Brown and Williamson, Minnesota Lawsuit 1969). Similar denial and minimisation of risks and promotion of a perception 
of controversy continue to be widespread in the field of radiation health risks. A brief discussion illustrating some concerns about key institutions in the field follows.

\section{The World Health Organization}

As the world's lead technical agency in health, with its assembly including all nations, WHO has great authority and convening power. Its reports, recommendations, technical standards, and guidelines command attention and respect. However, WHO's capacity is constrained by chronic budgetary shortages. In radiation and health there has been a lack of leadership as well as capacity, exacerbated by what is widely perceived as excessive deference and inadequate independence of WHO in relation to the International Atomic Energy Agency (IAEA). A 1959 agreement between the agencies stipulates: 'Whenever either organization proposes to initiate a program or activity on a subject in which the other organization has or may have a substantial interest, the first party shall consult the other with a view to adjusting the matter by mutual agreement' (IAEA 1959: Article 1.3).

The IAEA is structurally conflicted, as both global regulator of nuclear industry standards and safeguards, while at the same time promoting nuclear technology including power-in effect promoting the means for nuclear weapons proliferation, which it is also mandated to discourage (IAEA 1957). On some significant occasions, such as the 2006 multiagency UN report on the consequences of the Chernobyl nuclear disaster, the IAEA took the lead role in the report's conclusions, dissemination, and public comments while inappropriately downplaying the health impacts of the disaster (IAEA 2006). The report claimed only 4,000 excess deaths could be expected from the Chernobyl disaster; whereas the International Agency for Research on Cancer-WHO-linked but more research-active and independent - in the same year estimated 41,000 cancer cases and 16,000 (6,700-38,000) deaths to 2065 (Cardis et al. 2006).

WHO produced two landmark reports on the health effects of nuclear war (WHO 1983, 1987), the greatest potential source of radioactive exposure and contamination. The World Health Assembly recognised 'that nuclear weapons constitute the greatest immediate threat to the health and welfare of [hu] mankind' (WHO 1983). In 1987, the assembly decided that investigation of the health effects of nuclear war 
should be continued, and requested the WHO director-general to report periodically to the assembly on progress in this field. However no such follow-up has occurred.

In relation to the Fukushima nuclear disaster, WHO's role has been essentially limited to compiling a report on radiation doses, and a report assessing the health risks of those exposures (WHO 2012, 2013). It has had no active role in international input into the ongoing public health management of the disaster and protecting the health of the affected population. Raising questions about the Japanese government and about WHO's independence are reports of pressure by Vice-Minister Shinji Asonuma directly on the WHO director-general to reduce the estimated radiation doses to the thyroid glands of Japanese children as a result of the Fukushima nuclear disaster. The reported initial WHO estimates of 300-1,000 mSv in more contaminated areas and 10-100 $\mathrm{mSv}$ in Tokyo and Osaka were reduced to $100-200 \mathrm{mSv}$ and $1-10 \mathrm{mSv}$ respectively in the final WHO report, with the Japanese government reported to have sought further downward revision until moments before the report's release (Asahi Shimbun GLOBE 2014).

WHO's chronic budget crisis weakens its capacity, and its dependence on the goodwill of governments for a large proportion of its income undermines its independence. The WHO budget has increased from US $\$ 1.4$ billion in 1990-91 to US\$4.4 billion projected in 2016-17, yet over this time the assessed (regular) contributions of governments have remained stagnant at less than US\$1 billion annually. WHO thus now depends on voluntary contributions - many of them earmarked for specified purposes - from governments and charities for 79 per cent of its budget (WHO 2015).

\section{The International Commission on Radiological Protection}

The ICRP was established in 1928 and has had a major role in recommending radiation protection standards. It claims to be an independent organisation, committed to public benefit, impartial, transparent, and accountable. According to its 2014 annual report, it consists of 232 individuals from over 30 countries, nominated through an open process and invited to join as independent experts on a voluntary basis. Formally an independent registered charity in the UK, with a small secretariat in Canada, the ICRP operates as something of a club. Even a brief review of its website in July 2016 raises serious questions about its independence. Its assistant scientific secretary, Dr Haruyuki Ogino, 
is provided cost-free by the Central Research Institute of Electric Power Industry in Japan, that is, the commercial Japanese nuclear reactor operators. The ICRP membership includes a large number of employees of governments active in nuclear power and/or weapons, and employees of companies with clear vested nuclear interests, including Cameco, a large uranium mining company, Areva Resources Canada Inc., and nuclear reactor operators in the US, Europe, and Japan and their associations. A number of nuclear corporations also provide funding. These multiple layers of close involvement in a scientific body by vested interests is clearly improper by any usual standard.

Damning evidence of corruption and undue influence of vested interests in the ICRP was unearthed by the Fukushima Nuclear Accident Independent Investigation Commission established by the Japanese Diet (parliament) (NAIIC 2012). The commission found internal documents showing that the Federation of Electric Power Companies (FEPC) in Japan successfully lobbied radiation specialists, including members of the ICRP, so as to relax radiation protection standards, and minimise the radiation protection standards adopted in Japan. It emerged that the FEPC covered international travel costs for the ICRP's members from Japan under the guise of paying expenses for another group. The FEPC documents stated ' $[\mathrm{d}]$ ose constraints on occupational exposure should not be covered by regulation ... Special dose limits for women, special medical checkups for workers ... and legislated dose limits in case of emergency exposure should be abolished'. The outcome was that '[a]ll the views of the operators concerning the ICRP 2007 recommendations were reflected' (NAIIC 2012: Chapter 5, section 5.2.3). The ICRP has to date given no indication that it has addressed such corrupt and improper practices.

The Diet Commission also described reactor operators as seeking 'to steer research concerning the health effects of radiation in a direction that would find less damage and to steer the views of experts in Japan and elsewhere concerning radiation protection in a direction that would relax protection and control'. The FEPC documents stated, '[i]f it can be proven scientifically that the effects of dosage does not accumulate, significant relaxation including the review of dose limits can be expected in the future'. Mr Sakae Muto, former vice president of the Tokyo Electric Power Company, or TEPCO (owner and operator of the Fukushima 
nuclear plants), advised, '[k]eep an eye on the research trends so they won't be hijacked by bad researchers and pushed in a bad direction' (NAIIC 2012: Chapter 5, section 5.2.3).

\section{The United Nations Scientific Committee on the Effects of Atomic Radiation}

In the face of growing global concern and protest about atmospheric nuclear test explosions, their global radioactive fallout, and increasing levels of strontium-90 in the teeth of babies worldwide, UNSCEAR was established by the UN General Assembly in 1955. According to its website, 'purportedly with the intention to deflect a proposal calling for an immediate end to all nuclear explosions, it was proposed to the General Assembly of the United Nations that it establish a Committee to collect and evaluate information on the levels and effects of ionizing radiation' (UNSCEAR 2016). The creation of UNSCEAR was also related to the suspicion held by nuclear-armed states of an international movement of scientists through the United Nations Educational, Scientific and Cultural Organization and the International Council of Scientific Unions to sponsor scientific study of nuclear test fallout independently of governments (Herran 2014). Nestor Herran describes the scientific hegemony of the US and the UK in the early years of UNSCEAR, and the establishment of a pattern of downplaying the hazards of radioactive fallout-for example in the first major UNSCEAR report of 1958, omitting reference to carbon-14, which is responsible for the bulk of long-term human radiation exposure caused by nuclear tests (Ruff 2015).

Fifteen member states were initially designated as members; additional states were added in 1973 and 2011, to a current total of 27. Except for Sudan, which in 2016 signed a framework agreement with China for construction of nuclear power reactors, all the member states currently have nuclear weapons, nuclear power plants, and/or nuclear research reactors. Their UNSCEAR representatives and experts are governmentappointed, and are generally staff of their nuclear power or nuclear regulatory agencies. They therefore cannot be regarded as independent experts appointed on their scientific and medical merits. Some have close links with the nuclear industry, and there is overlap in membership with the ICRP. A notable example is Dr Douglas R. Boreham, who was the Canadian delegate to UNSCEAR in 2012 and a member of the Canadian delegation in other years, and who works for Bruce Power, a nuclear power company in Ontario. Dr Boreham's views on radiation risks do 
not reflect available evidence or the views of national or international radiation protection bodies in his repeated assertions that low-dose radiation does more good than harm, for example: 'If anything, there is health benefit instead of risk at low levels of exposure' (Higson et al. 2007: 259), and that CT scans may reduce rather than increase the risk of cancer (Scott et al. 2008). Dr Boreham has made at least three visits to Australia on behalf of uranium mining companies Toro Energy, Uranium One, and Heathgate Resources to undertake 'employee radiation training' and 'community consultation on radiation and health'-a euphemism for events designed to downplay and foment confusion about radiation risks (Toro Energy Limited 2008; MAPW 2012).

While many would hope and assume that international bodies like UNSCEAR and the ICRP would be pillars of independent rigour and scientific integrity protecting global health, like the extensive peerreviewed processes of the Intergovernmental Panel on Climate Change, in contrast these bodies are excessively dominated by vested government and commercial interests, lacking in transparency, inadequate in their ethical practices related to conflicts of interest of their members, and with a recurring pattern of selective interpretation of evidence and downplaying radiation risks. For example, UNSCEAR reports for years have dismissed as inconsistent with their preferred models the growing body of empiric evidence of significant effects of Chernobyl and Fukushima contamination on plants and animals discussed in Mousseau and Møller's chapter in this volume, and have ignored much of the evidence of health effects of the Chernobyl disaster.

\section{Potential future large-scale population radiation exposures}

While life on Earth has evolved with the constant evolutionary pressure and biological risks associated with background radiation, the advent of nuclear reactors and weapons has created unprecedented potential for radioactive releases enormous in size as well as extent in time and space. 


\section{Nuclear weapons}

The nuclear bombings of Hiroshima and Nagasaki, leaks and waste from nuclear weapons production, and a total of 2,056 nuclear test explosions are together responsible for the largest environmental radioactive contamination by human hands, and will continue to exact a toll in human health for many millennia (Ruff 2015). However, these pale in comparison to the potential population radiation exposure following a nuclear war (WHO 1987; IOM 1986), even one using a small fraction of the current global arsenal of 14,930 nuclear weapons (Kristensen and Norris 2017). The consequences of any given dose of radiation will be far worse after nuclear war because they will invariably co-exist with multiple other injuries, stresses, and health risks-and effectively functioning health services cannot be expected.

The risk of nuclear war is an ever-present danger as long as nuclear weapons exist, and is generally assessed by those most knowledgeable to be rising as a result of failure to implement disarmament; extensive nuclear modernisation programs of all the nuclear-armed states; 1,800 weapons still on high alert ready to be launched within a few minutes; growing risks of cyber-attack on nuclear command and control systems; deteriorating relationships and increasingly aggressive posturing of nuclear forces between the US/North Atlantic Treaty Organization (NATO) and Russia, between India and Pakistan, and in the South China Sea and the Korean Peninsula; and policies in many nuclear-armed states to use nuclear weapons first and potentially early in escalation of an armed conflict (Helfand et al. 2016). The hands of the Bulletin of the Atomic Scientists Doomsday Clock were moved from five to three minutes to midnight in 2015, kept there in 2016, and moved forward to two and a half minutes to midnight in 2017. Former US Defense Secretary William Perry and former Russian Foreign Minister Igor Ivanov are among those assessing the danger of nuclear war being greater now than it was during the Cold War, and growing (Helfand et al. 2016).

No effective medical response is feasible in the event of even a single nuclear detonation in a city, and the urgent elimination of nuclear weapons is the only means to durably prevent their otherwise inevitable use, and is therefore an absolute global health imperative. The decision by the United Nations General Assembly (2016: 4) to convene negotiations in 2017 on a 'legally binding instrument to prohibit nuclear weapons, leading towards their total elimination' is a historic opportunity to break the logjam in 
nuclear disarmament. In addition to prohibiting and eliminating nuclear weapons arsenals, achieving and sustaining a world freed from nuclear weapons will require controlling and eliminating the fissile materialshighly enriched uranium and separated plutonium - from which nuclear weapons can be built. This will require ending production and disposing of stockpiles as irreversibly as possible. It is the intrinsic capacity for uranium enrichment plants to be used to produce highly enriched uranium and for the plutonium inevitably created in nuclear reactors to be extracted from spent reactor fuel, that are the greatest planetary health dangers associated with the generation of nuclear power.

Ending production of highly enriched uranium (von Hippel and IPFM 2016), placing all uranium enrichment plants under international control (Diesendorf 2014), and ending reprocessing of spent nuclear fuel to extract plutonium (IPFM 2015b) would be important steps towards a safer world.

\section{Radioactive releases from nuclear facilities}

Nuclear facilities release radioactivity during routine operations, and minor accidents are very common. At nuclear power plants, large amounts of highly radioactive and long-lived materials accumulate in the reactor fuel, both in reactors and in the spent fuel pools where the intensely hot and radioactive used fuel must be cooled in circulating water for three to five years before it can be placed in dry storage. These pools do not have the multiple engineered layers of containment that reactors do, but are covered by a simple building. At the Fukushima Daiichi site at the time of the 2011 disaster, 70 per cent of the total onsite radioactivity was in the spent fuel pools (Stohl et al. 2011). Like reactors, these pools are vulnerable to fire and explosion if the continuous water cooling and the power that drives it are interrupted even briefly.

Official and vendor accounts state that the Fukushima Daiichi reactor core meltdowns only occurred as a result of the tsunami and not the earthquake itself. However, there is evidence that radioactive leaks began after the earthquake struck and before the tsunami hit (Stohl et al. 2011; NAIIC 2012). This has implications for every nuclear plant worldwide. Disruption to reactor and spent fuel pools cooling could occur as a result of some combination of poor design, construction faults, and natural disaster like earthquakes and tsunamis, as on 11 March 2011; or deliberately, by physical disruption to power supply or cooling 
water supply or circulation; or potentially by cyber-attack. The Israeli/ US-developed Stuxnet computer worm exposed in 2010 is perhaps the best-known example of a number of cyber-attacks on nuclear facilities since at least 1992. Stuxnet targeted the Siemens Step 7 SCADA system used by Iran's nuclear facilities, making uranium enrichment centrifuges spin too fast, partially destroying around 1,000 of them (Baylon, with Brunt and Livingstone 2015). An average-sized, 1 gigawatt nuclear power reactor contains more (and longer-lived) radioactivity than is released by a 1 megaton nuclear bomb (67 times the explosive yield of the bomb that destroyed Hiroshima). Thus, each of the 402 nuclear power reactors operating as at 1 July 2016 (Schneider et al. 2016) is in fact a potential huge, pre-positioned, radiological terrorist weapon ('dirty bomb').

There have been about 20 accidents worldwide since the early 1950s known to have resulted in melting of reactor cores (Burns, Ewing, and Navrotsky 2012). These have occurred in military and civilian reactors of various designs in different countries. Not all have resulted in releases of radioactivity into the environment, although all had the potential to do so. There have also been a total of 20 nuclear accidents categorised as Level 4 or higher at the severe end of the International Nuclear and Radiological Event Scale (INES). Level 4 accidents have local consequences, including 'release of significant quantities of radioactive material within an installation with a high probability of significant public exposure' (IAEA n.d.). Such accidents have occurred in Argentina, Canada, France, Japan, Slovakia, Switzerland, the UK, the US, and the USSR/Russia (Lelieveld, Kunkel, and Lawrence 2012). The actual historic frequency of core melt accidents is around one per 800 years of reactor operation (reactor years). For boiling water reactors with Mark 1 or 2 (early design) containments, like the Fukushima Daiichi reactors and many US reactors, the historic frequency of core melt accidents is around one in 630 years (Cochran 2011). Thus, with 400-odd nuclear reactors operating, a core melt accident can be expected every few years.

In Lelieveld and colleagues' analysis of the global frequency and fallout from major nuclear power reactor accidents (Lelieveld, Kunkel, and Lawrence 2012), on average more than 90 per cent of emitted cesium-137 would be transported beyond $50 \mathrm{~km}$ and about 50 per cent beyond $1,000 \mathrm{~km}$. They define more than 37 kilobecquerel per square metre $\left(\mathrm{kBq} / \mathrm{m}^{2}\right)$ of cesium-137 as significant contamination, being associated with a human radiation dose during the first year after a major accident of about $1 \mathrm{mSv}$. Using the Chernobyl disaster as the basis for estimating consequences, 
and the historic frequency of the worst category of accidents (INES Level 7-Chernobyl and Fukushima), they estimate that there are large parts of North America, East Asia, and Europe with risks of being contaminated by a major nuclear accident of more than 1 per cent per year. The average area contaminated with more than $40 \mathrm{kBq} / \mathrm{m}^{2}$ of cesium- 137 after a catastrophic core melt is $138,000 \mathrm{~km}^{2}$, affecting an average of 28 million people if such an accident occurred in Western Europe, and 34 million people if in South Asia.

\section{Dispersal of radioactive materials}

Dispersal of radioactive material in water or food supplies or with conventional explosives is technically simple, and there is abundant potential for access to radioactive materials. The most hazardous radiological materials available in large quantities are high-level radioactive waste (consisting of spent reactor fuel and wastes left from reprocessing of spent reactor fuel to extract plutonium) and plutonium separated from spent fuel. Around 505 tonnes of separated plutonium exists worldwide, about half of it in civilian facilities (IPFM 2015a). High-level waste is dangerously radioactive for many hundreds of thousands of years and must be strictly isolated from groundwater and the biosphere for up to 1 million years. The average nuclear power reactor produces 30 tonnes of high-level waste each year-around 12,000 tonnes annually worldwide, with a global total stockpile in 2015 of about 390,000 tonnes. No country yet has a functioning permanent repository for such waste, and the possibility of such material being stolen or diverted, particularly from a spent fuel reprocessing plant, and then deliberately dispersed in one or multiple cities is real and will exist over geological time frames. Such events could cause significant localised radioactive contamination.

\section{References}

Asahi Shimbun GLOBE, 2014. Revision demanded of the Fukushima radiation exposure report. 7 December.

Baker P. J., and D. G. Hoel, 2007. Meta analysis of standardised incidence and mortality rates of childhood leukaemia in proximity to nuclear facilities. European Journal of Cancer Care 16: 355-63. doi. org/10.1111/j.1365-2354.2007.00679.x 
Baylon, Caroline, with Roger Brunt, and David Livingstone, 2015. Cyber security at civil nuclear facilities: Understanding the risks. Chatham House Report. London: Royal Institute of International Affairs.

Brown and Williamson, Minnesota Lawsuit, 1969. Smoking and health proposal. Truth Tobacco Industry Documents. www.industrydocumentslibrary.ucsf.edu/tobacco/docs $/ \# \mathrm{id}=$ psdw0147 (accessed 19 January 2017).

Burns, Peter C., Rodney C. Ewing, and Alexandra Navrotsky, 2012. Nuclear fuel in a reactor accident. Science 335: 1184-8. doi. org/10.1126/science. 1211285

Cabinet Office, Consumer Affairs Agency, Reconstruction Agency, Ministry of Foreign Affairs, Ministry of Education, Culture, Sports, Science and Technology, Ministry of Health, Labour and Welfare, Ministry of Agriculture, Forestry and Fisheries, Ministry of Economy, Trade and Industry, Ministry of the Environment, and Secretariat of the Nuclear Regulation Authority (Japan), 2016. Basic information on radiation risk. February. www.reconstruction.go.jp/english/topics/ RR/index.html (accessed 19 January 2017).

Cardis, Elizabeth, Daniel Krewski, Mathieu Boniol, Vladimir Drozdovitch, Sarah C. Darby, Ethel S. Gilbert, Suminori Akiba, Jacques Benichou, Jacques Ferlay, Sarah Gandini, Catherine Hill, Geoffrey Howe, Ausrele Kesminiene, Mirjana Moser, Marie Sanchez, Hans Storm, Laurent Voisin, and Peter Boyle, 2006. Estimates of the cancer burden in Europe from radioactive fallout from the Chernobyl accident. International Journal of Cancer 119: 1224-35. doi.org/10.1002/ ijc. 22037

Centers for Disease Control and Prevention, 2015. Radiation and your health. 7 December. www.cdc.gov/nceh/radiation/health.html (accessed 6 March 2017).

Cochran, Thomas B., 2011. Statement on the Fukushima nuclear disaster and its implications for US nuclear power reactors. Testimony to the US Senate Joint Hearings of the Subcommittee on Clean Air and Nuclear Safety and the Committee on Environment and Public Works, 12 April. www.nrdc.org/sites/default/files/tcochran_110412.pdf (accessed 19 January 2017). 
Committee to Assess Health Risks from Exposure to Low Levels of Ionizing Radiation, 2006. Health Risks from Exposure to Low Levels of Ionizing Radiation: BEIR VII, Phase 2. Washington, DC: National Academies Press.

Dancause, Kelsey Needham, Lyubov Yevtushok, Serhiy Lapchenko, Ihor Shumlyansky, Genadiy Shevchenko, Wladimir Wertelecki, and Ralph M. Garruto, 2010. Chronic radiation exposure in the Rivne-Polissia region of Ukraine: Implications for birth defects. American Journal of Human Biology 22(5): 667-74. doi.org/10.1002/ajhb.21063

Diesendorf, Mark, 2014. Sustainable Energy Solutions for Climate Change. Sydney: UNSW Press.

Doll, Richard, and Richard Wakeford, 1997. Risk of childhood cancer from fetal irradiation. British Journal of Radiology 70: 130-9. doi. org/10.1259/bjr.70.830.9135438

European Nuclear Society, n.d. Radiation weighting factors. www.euronuclear.org/info/encyclopedia/r/radiation-weight-factor.htm (accessed 6 March 2017).

Fairlie, Ian, 2016. TORCH-2016: An independent scientific evaluation of the health-related effects of the Chernobyl nuclear disaster, Version 1.1. Vienna: GLOBAL 2000/Friends of the Earth Austria/Vienna Office for Environmental Protection, 31 March. www.global2000.at/ sites/global/files/GLOBAL_TORCH\%202016_rz_WEB_KORR.pdf (accessed 19 January 2017).

Gardner, Martin J., Michael P. Snee, Andrew J. Hall, Caroline A. Powell, Susan Downes, and John D. Terrell, 1990. Results of a case-control study of leukaemia and lymphoma among young people near Sellafield nuclear plant in West Cumbria. British Medical Journal 300: 423-9. doi.org/10.1136/bmj.300.6722.423

Gray, Alastair, Simon Read, Paul McGale, and Sarah Darby, 2009. Lung cancer deaths from indoor radon and the cost-effectiveness and potential of policies to reduce them. British Medical Journal 338: a3110. doi.org/10.1136/bmj.a3110

Helfand, Ira, Andy Haines, Hans Kristensen, Patricia Lewis, Zia Mian, and Tilman Ruff, 2016. The growing threat of nuclear war and the role of the health community. World Medical Journal 62(3): 86-94. 
Herran, Nestor, 2014. 'Unscare' and conceal: The United Nations Scientific Committee on the effects of atomic radiation and the origin of international radiation monitoring. In The Surveillance Imperative: Geosciences during the Cold War and Beyond, edited by Simone Turchetti and Peder Roberts, 69-84. New York: Palgrave Macmillan. doi.org/10.1057/9781137438744_4

Higson, D. J, D. R. Boreham, A. L. Brooks, Y-C. Luan, R. E. Mitchel, J. Strzelczyk, and P. J. Sykes, 2007. Effects of low doses of radiation: Joint statement from the following participants at the 15th Pacific Basin Nuclear Conference, sessions held in Sydney, Australia, Wednesday 18 October 2006. Dose-Response 5(4): 259-62. doi.org/10.2203/doseresponse.07-017.Higson

IAEA (International Atomic Energy Agency), 1957. The Statute of the IAEA (ratified 29 July 1957). www.iaea.org/about/statute (accessed 19 January 2017).

IAEA (International Atomic Energy Agency), 1959. Agreement between the International Atomic Energy Agency and the World Health Organization. www.ippnw.de/commonFiles/pdfs/Atomenergie/ Agreement_WHO-IAEA.pdf (accessed 19 January 2017).

IAEA (International Atomic Energy Agency), 2006. Chernobyl's legacy: Health, environmental and socio-economic impacts and recommendations to the governments of Belarus, the Russian Federation and Ukraine. The Chernobyl Forum: 2003-2005. 2nd rev. edn. IAEA/PI/A.87 Rev.2/06-09181. Vienna: IAEA.

IAEA (International Atomic Energy Agency), n.d. INES: The international nuclear and radiological event scale. www.iaea.org/sites/default/files/ ines.pdf (accessed 19 January 2017).

ICRP (International Commission on Radiological Protection), 2009. Application of the Commission's recommendations to the protection of people living in long-term contaminated areas after a nuclear accident or a radiation emergency. ICRP Publication 111. Annals of the ICRP 39(3).

IOM (Institute of Medicine), 1986. The Medical Implications of Nuclear War. Washington, DC: National Academy Press. 
IPFM (International Panel on Fissile Materials), 2015a. Global fissile material report 2015: Nuclear weapon and fissile material stockpiles and production. fissilematerials.org/library/gfmr15.pdf (accessed 19 January 2017).

IPFM (International Panel on Fissile Materials), 2015b. Plutonium separation in nuclear power programs: Status, problems, and prospects of civilian reprocessing around the world. fissilematerials.org/library/ rr14.pdf (accessed 27 June 2017).

Kaatsch, Peter, Claudia Spix, Renate Schulze-Rath, Sven Schmiedel, and Maria Blettner, 2008. Leukaemia in young children living in the vicinity of German nuclear power plants. International Journal of Cancer 1220: 721-6. doi.org/10.1002/ijc.23330

Kitahara, Cari M., Martha S. Linet, Preetha Rajaraman, and Estelle Ntowe, 2015. A new era of low-dose radiation epidemiology. Current Environmental Health Reports 2: 236-49. doi.org/10.1007/s40572015-0055-y

Kristensen, Hans M., and Matthew G. McKinzie, 2015. Nuclear arsenals: Current developments, trends and capabilities. International Review of the Red Cross 97(899): 563-99. doi.org/10.1017/ S1816383116000308

Kristensen, Hans M., and Robert S. Norris, 2017. Status of world nuclear forces (updated 8 July). Federation of American Scientists. fas.org/ issues/nuclear-weapons/status-world-nuclear-forces/ (accessed 7 September 2017).

Kuznick, Peter, 2011. Japan's nuclear history in perspective: Eisenhower and atoms for war and peace. Bulletin of the Atomic Scientists, 13 April.

Lelieveld J., D. Kunkel, and M. G. Lawrence, 2012. Global risk of radioactive fallout after major nuclear reactor accidents. Atmospheric Physics and Chemistry 12: 4245-58. doi.org/10.5194/acp-12-42452012 
Leuraud, Klervi, David B. Richardson, Elisabeth Cardis, Robert Daniels, Michael Gillies, Jacqueline A. O’Hagan, Ghassan B. Hamra, Richard Haylock, Dominique Laurier, Monika Moissonnier, Mary K. Schubauer-Berrigan, Isabelle Thierry-Chef, and Ausrele Kesminiene, 2015. Ionising radiation and risk of death from leukaemia and lymphoma in radiation-monitored workers (INWORKS): An international cohort study. Lancet Haematology 1: e276-81. doi. org/10.1016/S2352-3026(15)00094-0

Little, Mark. P., Tamara V. Azizova, Dimitry Bazyka, Simon D. Bouffler, Elisabeth Cardis, Sergey Chekin, Vadim V. Chumak, Francis A. Cucinotta, Florent de Vathaire, Per Hall, John D. Harrison, Guido Hildebrandt, Victor Ivanov, Valeriy V. Kashcheev, Sergiy V. Klymenko, Michaela Kreuzer, Olivier Laurent, Kotaro Ozasa, Thierry Schneider, Soile Tapio, Andrew M. Taylor, Ioanna Tzoulaki, Wendy L. Vandoolaeghe, Richard Wakeford, Lydia B. Zablotska, Wei Zhang, and Steven E. Lipshultzet, 2012. Systematic review and meta-analysis of circulatory disease from exposure to low-level ionizing radiation and estimates of potential population mortality risks. Environmental Health Perspectives 120(11): 1503-11. doi.org/10.1289/ehp.1204982

Makhijani, Arjun, Brice Smith, and Michael C. Thorne, 2006. Science for the vulnerable: Setting radiation and multiple exposure environmental health standards to protect those most at risk. Takoma Park, MD: Institute for Energy and Environmental Research, 19 October.

MAPW (Medical Association for Prevention of War), 2012. Toro Energy promotes radiation junk science. Statement of 45 medical doctors, May. www.mapw.org.au/download/doctors-slam-uraniumminer-over-junk-science-radiation-safety-statement-issued-mapw-1may-2 (accessed 19 January 2017).

Mathews, John, Anna Forsythe, Zoe Brady, Martin Butler, Stacy Goergen, Graham Byrnes, Graham Giles, Anthony Wallace, Philip Anderson, Tenniel Guiver, Paul McGale, Timothy Cain, James Dowty, Adrian Bickerstaffe, and Sarah Darby, 2013. Cancer risk in 680,000 people exposed to computed tomography scans in childhood or adolescence: Data linkage study of 11 million Australians. British Medical Journal 346: f2360. doi.org/10.1136/bmj.f2360 
Møller, Anders P., and Timothy A. Mousseau, 2013. The effects of natural variation in background radioactivity on humans, animals and other organisms. Biological Reviews 88: 226-54. doi.org/10.1111/j.1469185X.2012.00249.x

NAIIC (National Diet of Japan Fukushima Nuclear Accident Independent Investigation Commission), 2012. The official report of the Fukushima Nuclear Accident Independent Investigation Commission. Tokyo: National Diet of Japan.

National Research Council, 2012. Analysis of Cancer Risks in Populations near Nuclear Facilities: Phase 1. Washington, DC: National Academies Press.

Ozasa, Kotaro, Yukiko Shimizu, Akihiko Suyama, Fumiyoshi Kasagi, Midori Soda, Eric J. Grant, Ritsu Sakata, Hiromi Sugiyama, and Kazunori Kodama, 2012. Studies of the mortality of atomic bomb survivors, report 14, 1950-2003: An overview of cancer and noncancer diseases. Radiation Research 177(3): 229-43. doi.org/10.1667/ RR2629.1

Pearce, Mark S., Jane A. Salotti, Mark P. Little, Kieran McHugh, Choonsik Lee, Kwang Pyo Kim, Nicola L. Howe, Cecile M. Ronckers, Preetha Rajaraman, Sir Alan W. Craft, Louise Parker, and Amy Berrington de González, 2012. Radiation exposure from CT scans in childhood and subsequent risk of leukaemia and brain tumours: A retrospective cohort study. The Lancet 380(9840): 499-505. doi.org/10.1016/ S0140-6736(12)60815-0

Quigley, Dianne, Amy Lowman, and Steve Wing, 2012. Tortured Science: Health Studies, Ethics and Nuclear Weapons in the United States. Amityville, NY: Baywood Publishing Company Inc.

Richardson, David, Steve Wing, and Stephen R. Cole, 2013. Missing doses in the lifespan study of Japanese atomic bomb survivors. American Journal of Epidemiology 177(6): 562-8. doi.org/10.1093/aje/kws362 
Richardson, David B., Elisabeth Cardis, Robert D. Daniels, Michael Gillies, Jacqueline A. O’Hagan, Ghassan B. Hamra, Richard Haylock, Dominique Laurier, Klervi Leuraud, Monika Moissonnier, Mary K. Schubauer-Berrigan, Isabelle Thierry-Chef, and Ausrele Kesminiene, 2015. Risk from occupational exposure to ionizing radiation: Retrospective cohort study of workers in France, the United Kingdom, and the United States (INWORKS). British Medical Journal 351: h5359. doi.org/10.1136/bmj.h5359

Ruff, Tilman A., 2015. The humanitarian impact and implications of nuclear test explosions in the Pacific region. International Review of the Red Cross 97(899): 775-813. doi.org/10.1017/S1816383116000163

Schneider, Mycle, and Antony Froggatt, with Julie Hazemann, Ian Fairlie, Tadahiro Katsuta, Fulcieri Maltini, and M. V. Ramana, 2016. The World Nuclear Industry Status Report 2016. Paris: Mycle Schneider Consulting Project.

Scott, Bobby R., Charles L. Sanders, Ron E. J. Mitchel, and Douglas R. Boreham, 2008. CT scans may reduce rather than increase the risk of cancer. Journal of American Physicians and Surgeons 13(1): 8-11.

Smoll, Nicholas R., Zoe Brady, Katrina Scurrah, and John D. Mathews, 2016. Exposure to ionizing radiation and brain cancer incidence: The Life Span Study cohort. Cancer Epidemiology 42: 60-5. doi. org/10.1016/j.canep.2016.03.006

Soble, Jonathan, 2015. Japan to pay cancer bills for Fukushima worker. New York Times, 20 October.

Stohl, A., P. Seibert, G. Wotawa, D. Arnold, J. F. Burkhart, S. Eckhardt, C. Tapia, A. Vargas, and T. J. Yasunari, 2011. Xenon-133 and caesium-137 releases into the atmosphere from the Fukushima Dai-ichi nuclear power plant: Determination of the source term, atmospheric dispersion, and deposition. Atmospheric Chemistry and Physics Discussions 11(10): 28319-94. doi.org/10.5194/acpd-1128319-2011

Toro Energy Limited, 2008. Radiation information seminar. www.ausimm.com.au/Content/wir/doug_boreham_invit.pdf (accessed 19 January 2017). 
Tsuda, Toshihide, Akiko Tokinobu, Eiji Yamamota, and Etsuji Suzuki, 2016a. Thyroid cancer detection by ultrasound among residents ages 18 years and younger in Fukushima, Japan: 2011 to 2014. Epidemiology 27: 316-22. doi.org/10.1097/EDE.0000000000000385

Tsuda, Toshihide, Akiko Tokinobu, Eiji Yamamota, and Etsuji Suzuki, 2016b. Thyroid cancer under age 19 in Fukushima - As of 57 months after the accident. Presentation to the International Physicians for the Prevention of Nuclear War (IPPNW) Congress - Five Years Living With Fukushima, 30 Years Living With Chernobyl, Berlin, 27 February. www.tschernobylkongress.de (accessed 19 January 2017).

United Nations General Assembly, 2016. Taking forward multilateral nuclear disarmament negotiations. A/C.1/71/L.41, 14 October.

UNSCEAR (United Nations Scientific Committee on the Effects of Atomic Radiation), 1993. Sources and Effects of Ionizing Radiation: UNSCEAR 1993 Report to the General Assembly with Scientific Annexes. New York: United Nations.

UNSCEAR (United Nations Scientific Committee on the Effects of Atomic Radiation), 2014. Sources, Effects and Risks of Ionizing Radiation: UNSCEAR 2013 Report: Volume I. Scientific Annex A: Levels and Effects of Radiation Exposure Due to the Nuclear Accident after the 2011 Great East-Japan Earthquake and Tsunami. New York: United Nations. www.unscear.org/docs/reports/2013/13-85418_Report_2013 _Annex_A.pdf (accessed 19 January 2017).

UNSCEAR (United Nations Scientific Committee on the Effects of Atomic Radiation), 2016. Historical milestones. www.unscear.org/ unscear/about_us/history.html (accessed 19 January 2017).

US EPA (Environmental Protection Agency), 2014. Radiation risk assessment at CERCLA sites: Q\&A. EPA 540-R-012-13, May.

von Hippel, Frank, and IPFM (International Panel on Fissile Materials), 2016. Banning the production of highly enriched uranium. fissilematerials.org/library/rr15.pdf (accessed 27 June 2017).

Wahab, M. A, E. M. Nickless, R. Najar-M'Kacher, C. Parmentier, J. V. Podd, and R. E. Rowland, 2008. Elevated chromosome translocation frequencies in New Zealand nuclear test veterans. Cytogenetic and Genome Research 121: 79-87. doi.org/10.1159/000125832 
Wakeford, Richard, G. M. Kendall, and Mark P. Little, 2009. The proportion of childhood leukaemia incidence in Great Britain that may be caused by natural background radiation. Leukemia 23: 770-6. doi.org/10.1038/leu.2008.342

WHO (World Health Organization), 1983. Effects of Nuclear War on Health and Health Services. Geneva: World Health Organization.

WHO (World Health Organization), 1987. Effects of Nuclear War on Health and Health Services. 2nd edn. Geneva: World Health Organization.

WHO (World Health Organization), 2012. Preliminary dose estimation from the nuclear accident after the 2011 Great East Japan earthquake and tsunami. Geneva: World Health Organization.

WHO (World Health Organization), 2013. Health risk assessment from the nuclear accident after the 2011 Great East Japan earthquake and tsunami, based on a preliminary dose estimation. Geneva: World Health Organization.

WHO (World Health Organization), 2015. Investing in the World's Health Organization: Taking steps towards a fully-funded Programme Budget 2016-17. Financing Dialogue 2015. www.who.int/about/ finances-accountability/funding/financing-dialogue/ProgrammeBudget-2016-2017-Prospectus.pdf?ua=1 (accessed 19 January 2017). 
This text is taken from Learning from Fukushima: Nuclear power in East Asia, edited by Peter Van Ness and Mel Gurtov, published 2017 by ANU Press, The Australian National University, Canberra, Australia.

dx.doi.org/10.22459/LF.09.2017.08 